\title{
Murine Cytomegalovirus Infection Induces Susceptibility to EAE in Resistant BALB/c Mice
}

\author{
Jelena Milovanovic ${ }^{1,2}$, Branka Popovic ${ }^{3}$, Marija Milovanovic ${ }^{1}$, Daria Kvestak ${ }^{3}$, \\ Aleksandar Arsenijevic ${ }^{1}$, Bojana Stojanovic ${ }^{1,4}$, Irena Tanaskovic ${ }^{2}$, Astrid Krmpotic ${ }^{3}$, \\ Nebojsa Arsenijevic ${ }^{1}$, Stipan Jonjic ${ }^{3}$ and Miodrag L. Lukic ${ }^{1 *}$
}

\begin{abstract}
${ }^{1}$ Center for Molecular Medicine and Stem Cell Research, Faculty of Medical Sciences, University of Kragujevac, Kragujevac, Serbia, ${ }^{2}$ Faculty of Medical Sciences, Institute of Histology, University of Kragujevac, Kragujevac, Serbia, ${ }^{3}$ Center for Proteomics, Faculty of Medicine, Department for Histology and Embryology, University of Rijeka, Rijeka, Croatia, ${ }^{4}$ Faculty of Medical Sciences, Institute of Pathophysiology, University of Kragujevac, Kragujevac, Serbia
\end{abstract}

\section{OPEN ACCESS}

Edited by:

Luigi Daniele Notarangelo,

Harvard Medical School, USA

Reviewed by:

Silva Markovic-Plese,

University of North Carolina at Chapel

Hill, USA

Anne Kathrin Mausberg,

Essen University Hospital, Germany

*Correspondence:

Miodrag L. Lukic

miodrag.lukic@medf.kg.ac.rs

Specialty section: This article was submitted to Multiple Sclerosis and Neuroimmunology, a section of the journal Frontiers in Immunology

Received: 30 July 2016 Accepted: 09 February 2017 Published: 27 February 2017

Citation:

Milovanovic J, Popovic B, Milovanovic $M$, Kvestak $D$,

Arsenijevic A, Stojanovic $B$,

Tanaskovic I, Krmpotic A, Arsenijevic N, Jonjic S and Lukic ML (2017) Murine Cytomegalovirus Infection Induces Susceptibility to EAE in Resistant BALB/c Mice.

Front. Immunol. 8:192. doi: 10.3389/fimmu.2017.00192
In contrast to $\mathrm{C} 57 \mathrm{BL} / 6$ mice, BALB/c mice are relatively resistant to the induction of experimental autoimmune encephalomyelitis (EAE) after challenge with $\mathrm{MOG}_{35-55}$ peptide. Here, we provide the first evidence that infection with murine cytomegalovirus (MCMV) in adulthood abrogates this resistance. Infected BALB/c mice developed clinical and histological signs similar to those seen in susceptible C57BL/6 mice. In addition to CD4+ cells, large proportion of cells in the infiltrate of diseased BALB/c mice was $\mathrm{CD}^{+}$, similar with findings in multiple sclerosis. $\mathrm{CD} 8^{+}$cells that responded to ex vivo restimulation with $\mathrm{MOG}_{35-55}$ were not specific for viral epitopes pp89 and m164. MCMV infection favors proinflammatory type of dendritic cells $\left(\mathrm{CD} 86^{+} \mathrm{CD} 40^{+} \mathrm{CD} 11 \mathrm{C}^{+}\right)$in the peripheral lymph organs, M1 type of microglia in central nervous system, and increases development of Th1/Th17 encephalitogenic cells. This study indicates that MCMV may enhance autoimmune neuropathology and abrogate inherent resistance to EAE in mouse strain by enhancing proinflammatory phenotype of antigen-presenting cells, Th1/Th17, and CD8 response to $\mathrm{MOG}_{35-55}$.

Keywords: experimental autoimmune encephalomyelitis, BALB/c mice, murine cytomegalovirus infection, antigen-presenting cells, $T$ cells

\section{INTRODUCTION}

Multiple sclerosis (MS) is a chronic inflammatory, demyelinating disease of the central nervous system (CNS) with axonal injury, characterized by varying clinical course, pathology, and inflammatory patterns (1). It develops in susceptible hosts after interaction with environmental factors which trigger the disease by promoting the activation of myelin-specific $\mathrm{T}$ cells that normally circulate in the peripheral lymph organs of all individuals (2). It has been suggested that some infectious agents, in particular viruses, may be potential triggers of MS (2-4). Among different infective agents, Epstein-Barr virus (EBV) has been mostly associated with increased MS risk (5). Recently, it has been shown increased $\mathrm{CD} 8^{+} \mathrm{T}$ cell response to EBV lytic antigens in active MS and also in relapses (6). Infection with murine gamma herpesvirus 68 ( $\gamma \mathrm{HV}-68)$, the murine homolog to $\mathrm{EBV}$, polarizes the adaptive immune response and heightens CNS pathology following experimental autoimmune encephalomyelitis (EAE) induction and likely, influences MS pathogenesis (7). 
Experimental autoimmune encephalomyelitis is the experimental model of MS, induced in susceptible animals by active immunization with myelin antigens mixed with adjuvant (8). Immunized mice develop ascending paralysis with $\mathrm{CD}^{+} \mathrm{T}$ cells and macrophages in infiltrations in the white matter of the spinal cord, and with minimal brain inflammation in the majority of experimental models. However, in MS, the vast majority of myelin lesions are found within the brain parenchyma with infiltrations that contain equivalent numbers of $\mathrm{CD}^{+} \mathrm{T}$ and $\mathrm{CD} 4^{+} \mathrm{T}$ cells $(9,10)$. Despite these differences, EAE is considered as a valuable tool for research of MS pathogenesis. Moreover, several therapeutics that are now being used to treat MS were developed in EAE (11). BALB/c mice are found partially or completely resistant to the induction of EAE with encephalitogenic peptide, myelin oligodendrocyte glycoprotein ( $\left.\mathrm{MOG}_{35-55}\right)$.

Cytomegalovirus(CMV)classified within theBetaherpesvirinae subfamily establishes life-long latent infections in 70-100\% of the human population (12). After a primary infection of fibroblasts, epithelial, endothelial, and smooth muscle cells (6), mostly asymptomatic in the immunocompetent host, CMV persists in myeloid precursor cells (7). During latency periodic asymptomatic reactivations occur (13). CMV contains a large number of latent and lytic genes, many of which code proteins that have the role in immunoregulation (5). When monocytes that carry CMV enter visceral parenchyma and differentiate into macrophages and myeloid dendritic cells, virus reactivates and through expression of different genes can modulate the immune response of the host (14).

Data on the role of CMV infection in etiopathogenesis of MS are controversial. CMV has been found in demyelinating plaques and the cerebrospinal fluid of MS patients (15) and causes demyelination mainly in the CNS of immunocompromised hosts (16). Further, enhancement of numbers of EBV and CMV-specific $\mathrm{CD}^{+} \mathrm{T}$ cells among $\mathrm{T}$ cells in chronic inflammatory lesions of brain of MS patients was reported (17). Several studies involving human subjects indicate correlation between CMV infection and MS development, greater rate of relapses and greater brain atrophy (18-20). Other studies indicate that CMV seropositivity is associated with a decreased MS risk and predicts a better clinical and radiological outcome in MS patient (21), suggesting a protective effect of CMV on autoimmune neuropathology (22). Furthermore, CMV encodes multiple factors that trigger immunomodulatory or evasion mechanisms, which can decrease the immune response in MS patients $(23,24)$.

We have recently shown that deletion of an immunoregulatory pathway, IL-33/ST2 axis, may enhance susceptibility to EAE in resistant $\mathrm{BALB} / \mathrm{c}$ strain $(25,26)$. The present study was done with the aim to explore whether infection with murine CMV (MCMV) create "fertile field" $(27,28)$ that facilitates the expansion and activation of encephalitogenic cells leading to autoimmune disease of CNS.

Here, we show that MCMV infected and $\mathrm{MOG}_{35-55}$ immunized $\mathrm{BALB} / \mathrm{c}$ mice develop very pronounced neuroinflammation with extensive infiltrations in brain and spinal cord parenchyma containing large proportion of $\mathrm{CD}^{+}$cells in infiltrates in addition to accentuation of Th1 and Th17 immune response and skewing microglia to M1 phenotype. Our results are compatible with the notion that MCMV abrogates inherent resistance of BALB/c mice to EAE induction with $\mathrm{MOG}_{35-55}$ peptide through enhancement of inflammatory dendritic cells in the periphery, M1 type of microglia and recruitment of $\mathrm{MOG}_{35-55}$ responsive $\mathrm{CD}^{+} \mathrm{T}$ cells in the CNS. Thus, CMV-induced inflammatory environment may enhance autoimmunity in CNS.

\section{MATERIALS AND METHODS}

\section{Infection, Induction, and Scoring of EAE}

Female 8-week-old BALB/c mice were used throughout this study. Mice were infected subcutaneously (footped) with $10^{5}$ plaque-forming units of tissue culture MCMV, strain MW97.01 (29). EAE was induced 10 days after infection by subcutaneous administration of $200 \mu \mathrm{L}$ suspension at two sites over the hind flanks. Depletion of $\mathrm{CD}^{+}$lymphocytes, where indicated, was performed with intraperitoneal injection of $100 \mu \mathrm{g}$ of anti-CD4 $\mathrm{mAb}, 1$ day prior to and 5 days after $\mathrm{MOG}_{35-55}$ immunization. The suspension consisted of $300 \mu \mathrm{g} \mathrm{MOG}_{35-55}$ peptide (SigmaAldrich, Germany) in $100 \mu \mathrm{L}$ of PBS, emulsified with $100 \mu \mathrm{L}$ complete Freund's adjuvant (Sigma-Aldrich, Germany) with $0.7 \mathrm{mg}$ heat-inactivated Mycobacterium tuberculosis (strain H37 RA; Difco Laboratories, Detroit, MI, USA). Each mouse was immediately thereafter, injected intraperitoneally and $48 \mathrm{~h}$ later with $300 \mathrm{ng}$ pertussis toxin (List Biological Laboratories, Campbell, CA, USA) in $100 \mu \mathrm{L} 0.9 \% \mathrm{NaCl}$. Clinical signs of EAE were assessed daily by the following scoring system: grade 0 , no signs; grade 1, paralyzed tail; grade 2, ataxic; grade 2.5, one hind leg paralyzed; grade 3 , both hind legs paralyzed; grade 3.5 , three legs paralyzed; grade 4 , both hind legs and front limbs completely paralyzed; grade 5 , moribund as previously described $(30,31)$. Mice were monitored daily with fluid administration and mashed chow on the base of cages for all mice displaying a clinical score of 3 . Mice were maintained in our animal facilities in a temperature-controlled environment with a 12-h light/12-h dark cycle and were administered standard laboratory food and water ad libitum. All experiments were approved by and conducted in accordance with the Guidelines of the Animal Ethics Committee of Faculty of Medical Sciences, University of Kragujevac, Serbia. Endangered animal species were not used in this study.

\section{Isolation of Mononuclear Cells from CNS and Lymph Nodes}

At day 15 post-EAE induction (mean clinical score of 3 for MCMV EAE mice), mice were perfused with PBS, and brain and spinal cord were carefully removed. The mononuclear cells from CNS were isolated as described previously (25). Briefly, the brains and spinal cords were homogenized in RPMI 1640 (Sigma-Aldrich) with $10 \% \mathrm{FBS}$ and $1 \mathrm{mg} / \mathrm{mL}$ collagenase type I (Sigma-Aldrich) and incubated at $37^{\circ} \mathrm{C}$ for $60 \mathrm{~min}$. After digestion, the tissue was passed through a $40-\mu \mathrm{m}$ mesh, pelleted, resuspended in $10 \mathrm{~mL}$ $30 \%$ Percoll (Sigma-Aldrich), overlaid onto $5 \mathrm{~mL} 70 \%$ Percoll, and centrifuged at $390 \mathrm{~g}$ for $20 \mathrm{~min}$. The myelin layer was removed, and the mononuclear cells accumulated in the intermediate 
phase were collected, washed twice in PBS, and resuspended in RPMI 1640 containing 10\% FBS. Total cell numbers were determined by counting on a hemocytometer, and viability was assessed by trypan blue exclusion. Lymph nodes were minced in

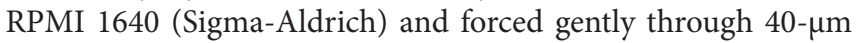
cell-strainer nylon mesh (Falcon) using a sterile syringe plunger and centrifuged at $400 \mathrm{~g}$ for $5 \mathrm{~min}$. Pellet from lymph nodes was resuspended in RPMI 1640 containing 10\% FBS.

\section{Flow Cytometry}

Single-cell suspensions of brain and spinal cord tissue were prepared according to standard protocols. For cytofluorometry, following antibodies were used: CD4, CD8, CD45, CCR6, CXCR3, TCR $\beta$, CD11c, CD11b, CD49b, CCR2, CD86, T-bet, ROR $\gamma$, IL-17, IFN- $\gamma$, TNF- $\alpha$, and IL-12 with conjugated fluorochromes (BD Biosciences). Antibodies were incubated with cells in PBS with $2 \% \mathrm{FBS}$ for $30 \mathrm{~min}$ at $4^{\circ} \mathrm{C}$, and then cells were analyzed. For intracellular staining of cytokines, cells were stimulated for $4 \mathrm{~h}$ in RPMI 1640 containing 10\% FBS (Gibco), $10 \mathrm{ng} / \mathrm{mL}$ phorbol 12-myristate 13-acetate (Sigma-Aldrich), and $500 \mathrm{ng} / \mathrm{mL}$ ionomycin (Sigma-Aldrich) with addition of Brefeldin A (BD Biosciences). Antibodies for the cell surface markers were added to the cells in PBS with 2\% FBS for 30 min on ice. After wash, cells were resuspended in Cytofix/Cytoperm buffer (BD Biosciences) for 20 min on ice, washed twice, and incubated with Abs for intracellular antigens (cytokines) in Perm buffer (30 min, on ice). For staining of transcriptional factors, unstimulated cells were used. Data were acquired using FACSCalibur (BD Biosciences) and analyzed with FlowJo software (Tree Star).

\section{Tetramer Staining}

Immune cells were isolated as described above. Cells isolated from CNS were incubated with H-2L(d)/IE-1/pp89 (168-176 YPHFMPTNL) and H-2D(d)/m164 (257-265 AGPPRYSRI) tetramers provided by NIH tetramer core facility. Cells stained with tetramer and anti-CD8 and anti-CD3 antibodies were incubated for $30 \mathrm{~min}$ at room temperature and then washed. Data were acquired using a FACSCalibur (BD Biosciences) and analyzed with FlowJo software (Tree Star).

\section{Immunohistochemistry and Evaluation of Brain and Spinal Cord Pathology}

Brains and spinal cords were fixed in $4 \%$ buffered formalin fixative overnight. Paraffin wax embedded sections $(5 \mu \mathrm{m})$ were stained with hematoxylin and eosin and CD3 (ab699; Abcam) immunohistochemical staining. The slides were analyzed on light microscope (BX51; Olympus), and digital images were acquired by digital camera. The level of infiltration was graded using the following score: 0 , no inflammatory cells; 1 , a few scattered inflammatory cells; 2, organization of inflammatory infiltrates into perivascular cuffs; 3 , extensive perivascular cuffing with extension into adjacent subarachnoid space and CNS parenchyma, and 4, extensive perivascular cuffing with increasing subarachnoid and parenchymal inflammation (32). Slides were analyzed on Olympus BX51 microscope, and digital images were acquired by Olympus digital camera (DP71).

\section{Interferon- $\boldsymbol{\gamma}$ Assay}

Mononuclear cells isolated from CNS, $10^{5}$ in $100 \mu \mathrm{L}$ complete media were put on 96 -well plate in duplicates, and $100 \mu \mathrm{L}$ of media, or $\mathrm{MOG}_{35-55}(1 \mu \mathrm{g} /$ well $)$ were added. After incubation for $1 \mathrm{~h}$ on $37^{\circ} \mathrm{C}, 0.2 \mu \mathrm{L}$ of Brefeldin $\mathrm{A}$ in $10 \mu \mathrm{L}$ of medium was added to each well and incubated for $4 \mathrm{~h}$ on $37^{\circ} \mathrm{C}$. Cells were washed and then incubated with anti-CD8 and anti-CD4 antibodies on $+4^{\circ} \mathrm{C}$ for $15 \mathrm{~min}$. After washing, cells were resuspended in Cytofix/ Cytoperm buffer for $30 \mathrm{~min}$ on ice, washed twice, and incubated with anti-IFN $\gamma$ antibodies diluted in Perm wash buffer (30 min, on ice) and resuspended in FACS media.

\section{Statistical Analysis}

All statistics were carried out using SPSS 18.0 for Windows software. Results were analyzed using the Student's $t$-test or Mann-Whitney test and ANOVA or Kruskal-Wallis. Data in this study were expressed as the mean + SEM. Values of $P<0.05$ were considered significant.

\section{RESULTS}

\section{Infection in Adult Life Abrogates Resistance to EAE in BALB/c Mice}

$\mathrm{BALB} / \mathrm{c}$ mice immunized with $\mathrm{MOG}_{35-55}$ did not develop clinical signs of EAE, while BALB/c mice infected with MCMV 8 weeks after birth and 10 days later challenged with $\mathrm{MOG}_{35-55}$ in CFA and pertussis toxin $\left(\mathrm{MCMV}+\mathrm{MOG}_{35-55}\right)$ developed clinical signs that correspond to EAE manifestations seen in C57BL/6 mice (Figure 1A). Based on evaluation of clinical course (Figure 1A) and mean maximal clinical score (Figure 1B), $\mathrm{MCMV}$-infected BALB/c mice developed disease indistinguishable from disease in susceptible $\mathrm{C} 57 \mathrm{BL} / 6$ mice. Infiltration in $\mathrm{CNS}$ of $\mathrm{MCMV}+\mathrm{MOG}_{35-55}$, expressed by mean histological score (Figure 1D) and total cell number (Figure 1C), was significantly higher compared with BALB/c mice immunized with $\mathrm{MOG}_{35-55}$ only mice. BALB/c mice infected with MCMV and 10 days later immunized with MOG $_{35-55}$ developed subarachnoid and perivascular infiltrations in the brain cortex, perivascular infiltrations in brainstem and cerebellum with spreading to parenchyma (Figure 1E), and white matter spinal cord infiltrations (Figure 1F). Single-cell infiltrates were detected in brains and spinal cords of $\mathrm{MOG}_{35-55}$-immunized mice only, and mild perivascular infiltrations were detected in brainstem of MCMV-infected mice (Figures 1E,F). Immunostaining of spinal cord sections showed presence of $\mathrm{CD}^{+}$cells in the infiltrates (Figure 1G).

\section{CNS Infiltrates of MCMV + MOG $_{35-55}$ Mice Contain Higher Amounts of T1/T17 CD4 ${ }^{+}$ and $\mathrm{CD}^{+}{ }^{+} \mathrm{T}$ Cells}

Further analysis showed significantly higher number of $\mathrm{CD}^{+}$ and $\mathrm{CD}^{+} \mathrm{T}$ cells in the infiltrates of $\mathrm{MCMV}+\mathrm{MOG}_{35-55}$ mice compared with $\mathrm{MOG}_{35-55}$ mice (Figure 2A). In the CNS of $\mathrm{MCMV}+\mathrm{MOG}_{35-55}$ mice, there was higher number of $\mathrm{CD}^{+} \mathrm{T}$ cells then $\mathrm{CD}^{+} \mathrm{T}$ cells, similar to typical EAE in C57BL/6 mice. 

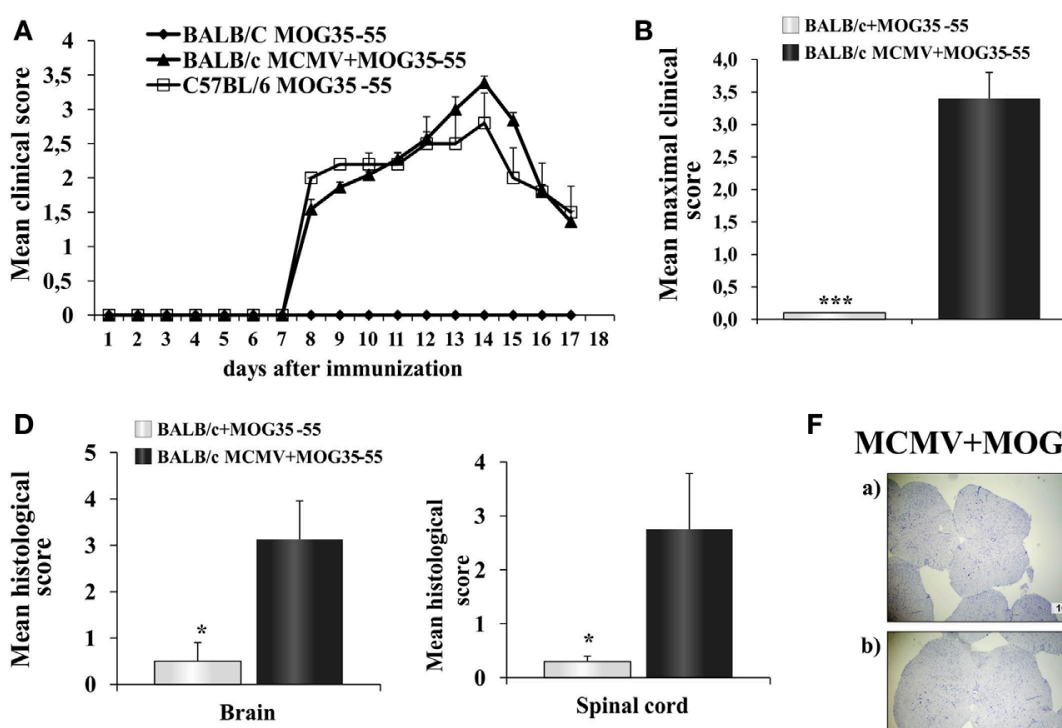

E $\quad M C M V+M_{35-55}$
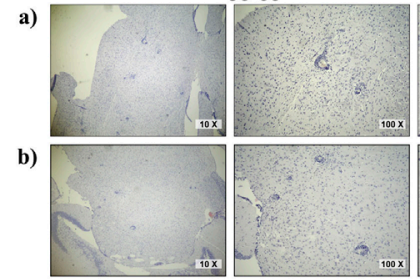

c)
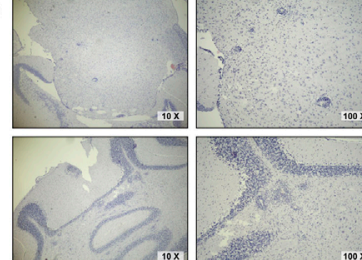

MCMV
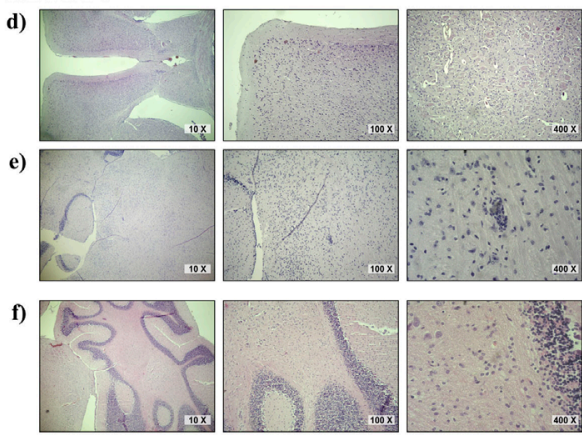

$\mathbf{M O G}_{35-55}$
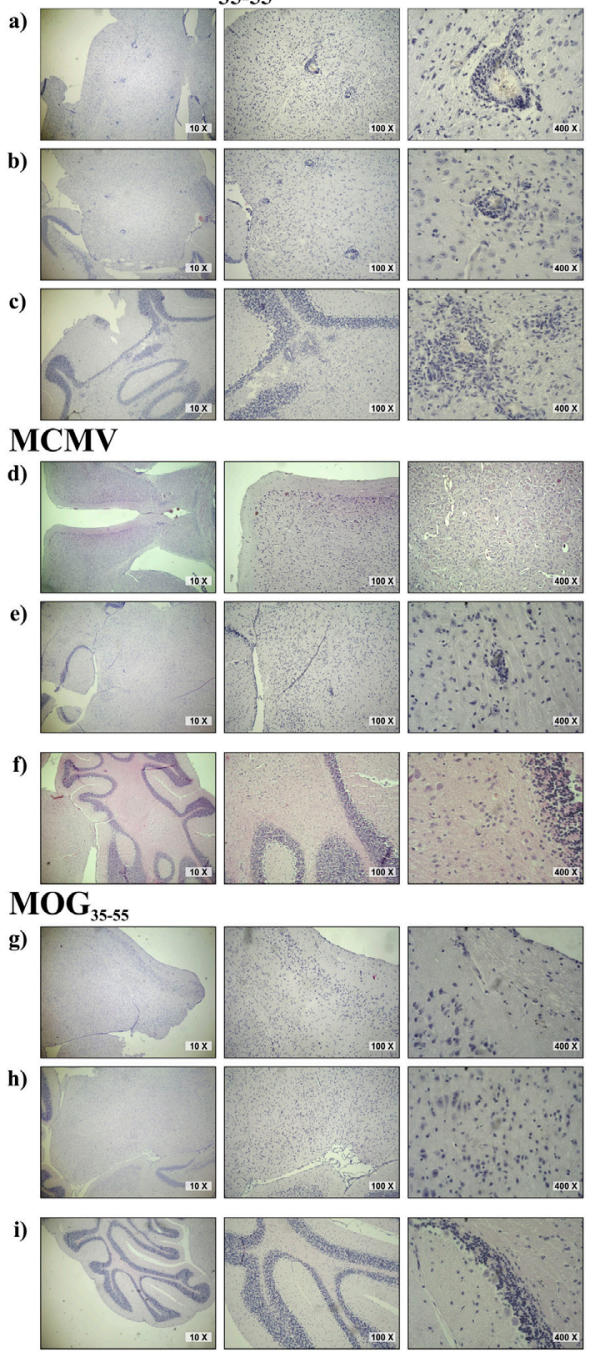

$\mathrm{MCMV}+\mathrm{MOG}_{35-55}$
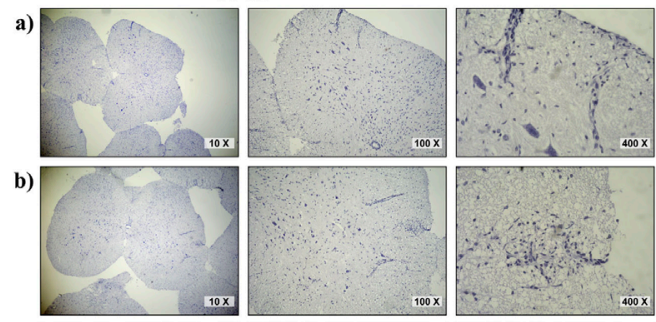

c)
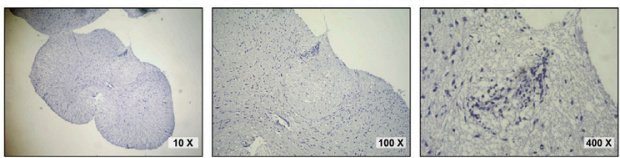

MCMV
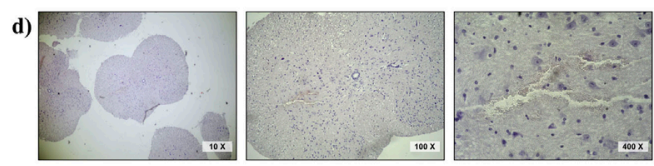

MOG $_{35-55}$
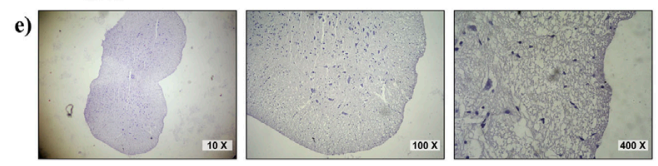

G $\quad \mathrm{MCMV}+\mathrm{MOG}_{35-55}$

a)

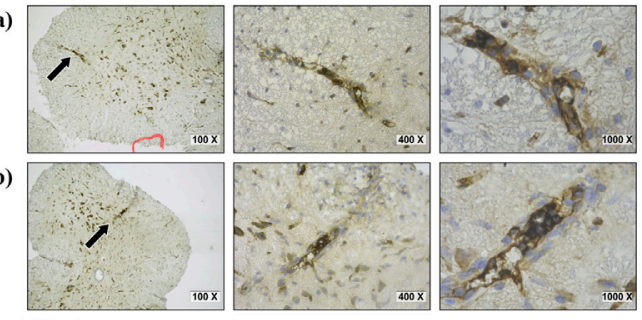

\section{MCMV}
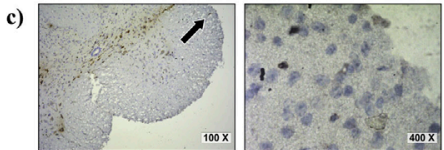

MOG $_{\text {35-55 }}$

d)
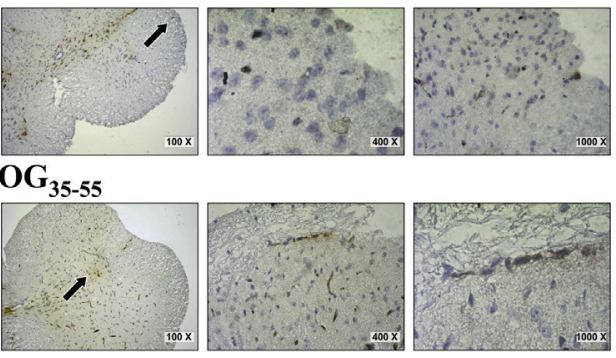

FIGURE 1 | Continued 


\section{FIGURE 1 | Continued}

BALB/c mice infected with murine cytomegalovirus (MCMV) and immunized with MOG $_{35-55}$ develop experimental autoimmune encephalomyelitis (EAE). Eight-week-old BALB/c mice were infected (foot-pad injection) with MCMV and 10 days after were immunized with $\mathrm{MOG}_{35-55}$ peptide in $\mathrm{CFA}_{\text {and }}$ pertussis toxin (BALB/C MCMV + MOG ${ }_{35-55}$ ). Control mice C57BL/6 and BALB/c were immunized with $\mathrm{MOG}_{35-55}$ peptide in CFA and pertussis toxin without previous infection

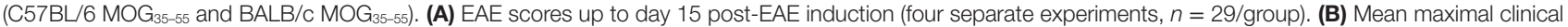
score up to day 15 post-EAE induction (four separate experiments, $n=29 /$ group). (C) The mean value of the mononuclear cells isolated from central nervous system (CNS) of BALB/c MCMV + MOG $35-55$ and BALB/c MOG ${ }_{35-55}$ mice (three independent experiments, $n=24 /$ group). (D) Mean histological scores were calculated from a total of five sections per group (two separate experiments, $n=8 /$ group). (E) The representative images of brain cortex (a), brain stem (b), cerebellum (c) of BALB/c MCMV + MOG ${ }_{35-55}$; brain cortex (d), brain stem (e), cerebellum (f) of BALB/c MCMV-infected mice (BALB/c MCMV); and brain cortex (g), brain stem (h), cerebellum (i) of BALB/c MOG $\mathrm{M}_{35-55}$ mice. (F) The representative images of spinal cords of BALB/c MCMV + MOG $35-55$ (a-C); BALB/c MCMV (d); and BALB/c MOG ${ }_{35-55}$ mice (e). (G) Representative sections of CD3 spinal cord immunohistochemistry of BALB/c MCMV + MOG $35-55$ (a,b); BALB/c MCMV (c); and $B A L B / c M_{35-55}$ mice (d), arrows in left panels indicate the area presented in magnified sections in right panels. All pictures are representative of two separate experiments ( $n=16 /$ group). Data were analyzed by Student's $t$-test and presented as mean $+\mathrm{SE}:{ }^{\star} P<0.05$ and ${ }^{* \star \star} P<0.001$.

$\mathrm{MCMV}+\mathrm{MOG}_{35-55}$ mice had increased percentage (Figure 2B) and number (Figure 2C) of both Th1 and Th17 cells, as well as Tc1 and Tc17 cells compared to $\mathrm{MOG}_{35-55}$ mice. Similarly, significantly higher number of $\mathrm{CD}^{+}$cell- and $\mathrm{CD}^{+}$cell-expressing transcriptional factors, T-bet and ROR $\gamma \mathrm{t}$ (Figure 2D), and chemokine receptors CCR6 and CXCR3 (Figure 2E) was noticed in CNS of $\mathrm{MCMV}+\mathrm{MOG}_{35-55}$ mice compared with $\mathrm{MOG}_{35-55}$ mice.

\section{CD8 ${ }^{+}$Cells Take a Role in Autoimmune Neuropathology in BALB/c Mice with MCMV Infection}

Depletion of $\mathrm{CD}^{+}$cells in MCMV-infected mice abrogated susceptibility to $\mathrm{MOG}_{35-55}$-induced disease (Figure $3 \mathbf{A}$ ) indicating autoimmune disease. Given the significant number of $\mathrm{CD}^{+}$cells in the infiltrates that were not seen in classical EAE, we explored in more details these cells found in CNS. There was significantly higher percentage and number of $\mathrm{CD}^{+}$cell-expressing markers of cytolytic activity in the CNS of $\mathrm{MCMV}+\mathrm{MOG}_{35-55} \mathrm{BALB} / \mathrm{c}$ mice compared to $\mathrm{MOG}_{35-55}$ mice (Figure 3B). To indirectly determine the percentage of $\mathrm{MOG}_{35-55}$-specific $\mathrm{CD}^{+}$and $\mathrm{CD}^{+}$cells, mononuclear cells were isolated from CNS of $\mathrm{MCMV}+\mathrm{MOG}_{35-55}$ $\mathrm{BALB} / \mathrm{c}, \mathrm{MOG}_{35-55} \mathrm{BALB} / \mathrm{c}$, and $\mathrm{MOG}_{35-55} \mathrm{C} 57 \mathrm{BL} / 6$ mice and $e x$ vivo restimulated with $\mathrm{MOG}_{35-55}$ peptide, and IFN- $\gamma^{+}$cells were enumerated. Significantly higher percentage of $\mathrm{CD}^{+}$and $\mathrm{CD} 8^{+}$ cells from CNS of $\mathrm{MCMV}+\mathrm{MOG}_{35-55}$ mice responded to ex vivo restimulation compared with $\mathrm{MOG}_{35-55}$ only $\mathrm{BALB} / \mathrm{c}$ mice (Figure 3C). Further, significantly higher percentage of $\mathrm{CD}^{+}$ cells isolated from CNS of MCMV $+\mathrm{MOG}_{35-55} \mathrm{BALB} / \mathrm{c}$ mice contained IFN- $\gamma$ after ex vivo restimulation with $\mathrm{MOG}_{35-55} \mathrm{com}-$ pared to $\mathrm{C} 57 \mathrm{BL} / 6$ mice immunized with $\mathrm{MOG}_{35-55}$. Even more importantly, IFN- $\boldsymbol{\gamma}$-containing $\mathrm{CD}^{+}$cells in $\mathrm{MCMV}+\mathrm{MOG}_{35-55}$ $\mathrm{BALB} / \mathrm{c}$ mice after restimulation with $\mathrm{MOG}_{35-55}$ were not specific for viral epitopes pp89 and m164, suggesting that inflammatory $\mathrm{CD}^{+}$cells in the CNS are autoimmune (Figure 3D).

\section{Chronic Non-Productive MCMV Infection Also Facilitates EAE Development in BALB/c Mice}

In order to test whether the chronic non-productive MCMV infection could facilitate EAE development, we immunized $\mathrm{BALB} / \mathrm{c}$ mice with $\mathrm{MOG}_{35-55}$ peptide 3 months after MCMV infection in adult life. As shown in Figure 4, infected mice developed clinical signs of EAE while age-matched mice immunized with encephalitogen only, did not. Mice with chronic non-productive MCMV infection started to manifest signs of EAE 6 days after immunization with $\mathrm{MOG}_{35-55}$ peptide; maximal clinical score reached 15 days after immunization and had very mild signs of the disease 60 days after immunization (Figure 4A). Chronic disease was confirmed with histological analysis. Perivascular infiltrates were detected in the spinal cords of mice with latent MCMV infection 2 months after challenge with $\mathrm{MOG}_{35-55}$ peptide (Figure 4B). Among cells isolated from brains of MCMV-infected $\mathrm{BALB} / \mathrm{c}$ mice 2 months after $\mathrm{MOG}_{35-55}$ immunization, higher percentage of $\mathrm{CD}^{+}$and $\mathrm{CD}^{+}$cells contained inflammatory cytokines IL-17 and IFN- $\gamma$, after in vitro restimulation with $\mathrm{MOG}_{35-55}$ peptide compared to stimulated cells isolated from $\mathrm{MOG}_{35-55}$-immunized mice (Figure 4C). Our findings indicate that $\mathrm{BALB} / \mathrm{c}$ mice with latent MCMV infection develop disease with long-lasting infiltrates in the CNS that contains lymphocytes specific for neuroantigens.

\section{Infection Induces Inflammatory Phenotype of Antigen-Presenting Cells in Periphery and in CNS}

It is known that viral infection induces antiviral immune response mediated by NK cells, $\mathrm{CD}^{+}$and $\mathrm{CD} 4^{+}$lymphocytes (33). Such inflammatory microenvironment in peripheral lymph organs can affect activation of antigen-presenting cells and thus indirectly contribute to development of inflammatory lymphocytes. Therefore, we explored possible influence of viral infection on changes of phenotype of antigen-presenting cells. To this end, mononuclear cells were isolated from inguinal lymph node 12 days after MCMV was administered in foot pad and compared with cells isolated from mice immunized with $\mathrm{MOG}_{35-55}$ only. Lymph nodes of MCMV-infected and MCMV + $\mathrm{MOG}_{35-55}$ mice had significantly higher percentage of $\mathrm{CD}_{11 \mathrm{c}^{+}}$dendritic cells and $\mathrm{CD} 11 \mathrm{c}^{+} \mathrm{PDCA} 1^{+}$plasmocitoid dendritic cells in inguinal lymph nodes compared to $\mathrm{MOG}_{35-55}$-immunized mice (Figure 5A). Also higher percentage of dendritic cell-expressing CCR2 chemokine receptor was found in both groups of MCMVinfected mice (Figure 5B). More importantly, lymph nodes of MCMV-infected and $\mathrm{MCMV}+\mathrm{MOG}_{35-55}$ mice contained higher percentage of activated $\mathrm{CD}^{+} 6^{+}$and $\mathrm{CD} 40^{+}$(Figure 5C) and inflammatory $\mathrm{IL}-12^{+}$dendritic cells (Figure 5E). Higher 


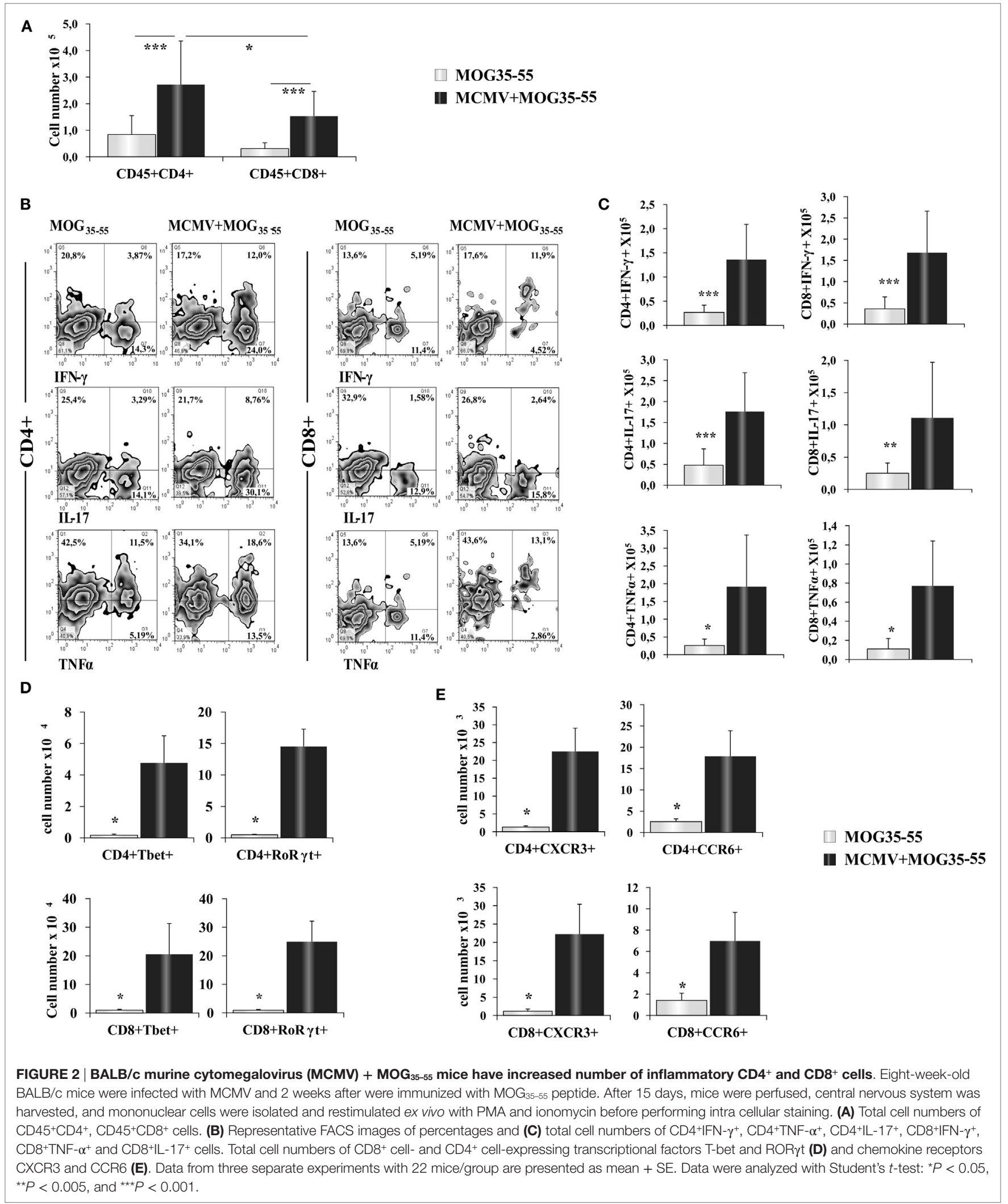




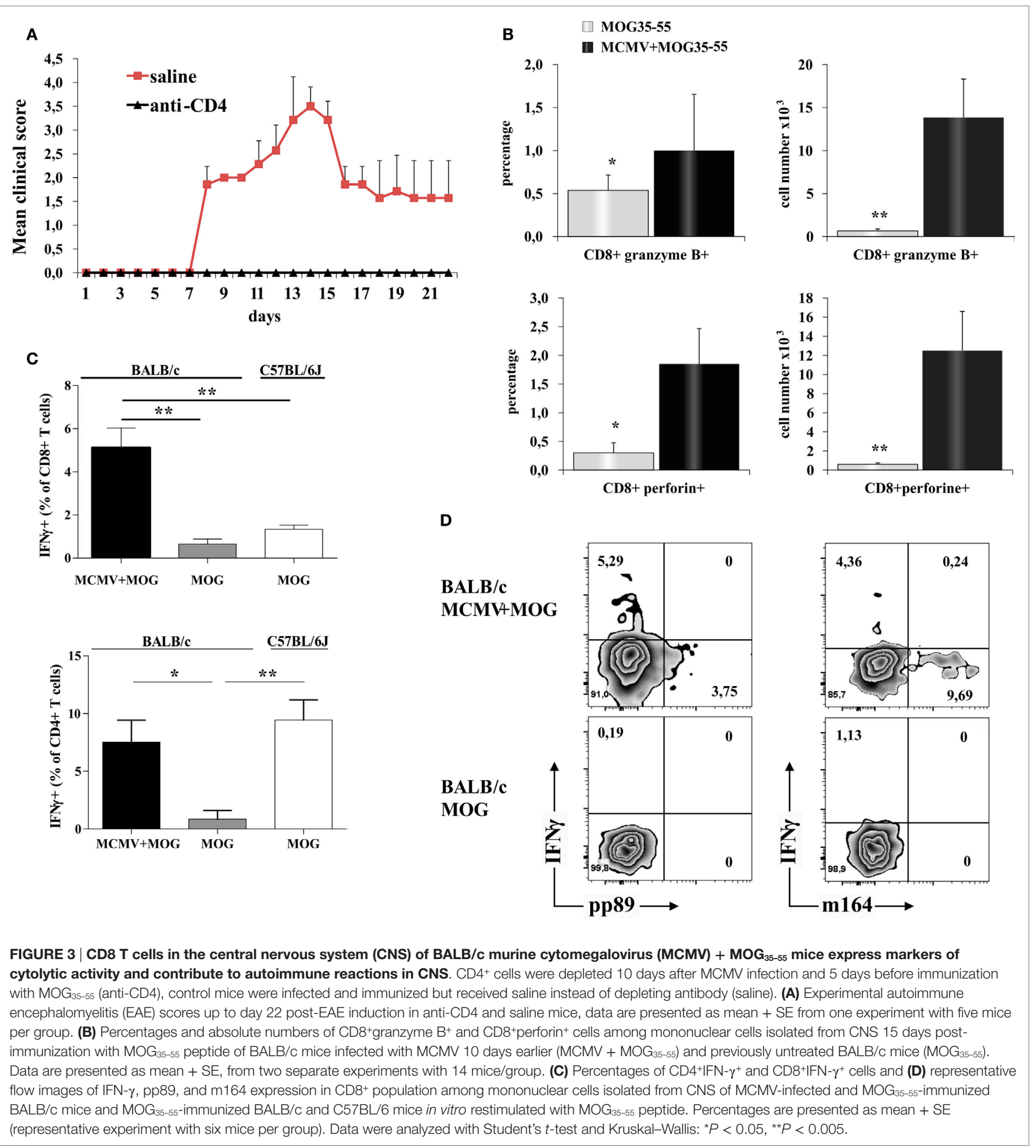

expression of markers of activation, $\mathrm{CD}^{+} 6^{+}$and $\mathrm{CD} 40^{+}$was noticed in MCMV-infected mice compared with $\mathrm{MOG}_{35-55^{-}}$ immunized mice (Figure 5D). These data suggest that inflammatory phenotype of dendritic cells is achieved in BALB/c mice with viral infection but not with encephalitogenic challenge only, as it was seen in C57BL/6 mice.
It is known that systemic inflammation in mice causes activation of microglia that persists for months $(34,35)$. Since MCMV infection in BALB/c mice causes systemic inflammation, we wanted to see effect of MCMV infection on phenotype of antigen-presenting cells in CNS. We analyzed expression of markers of classical (CD11c) and alternative activation 


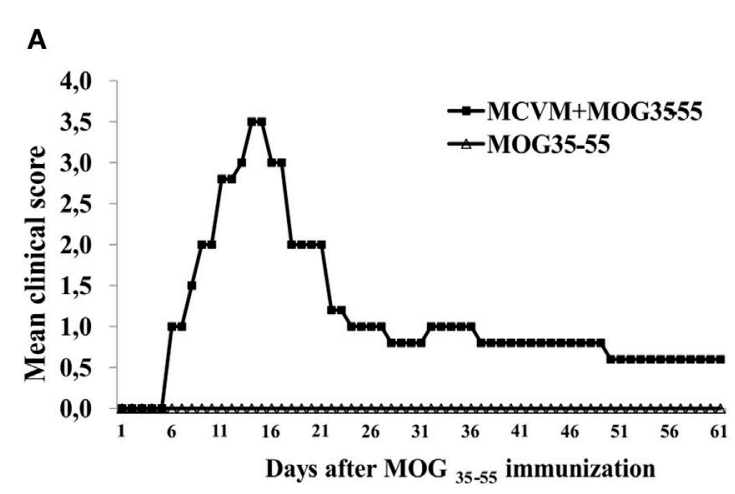

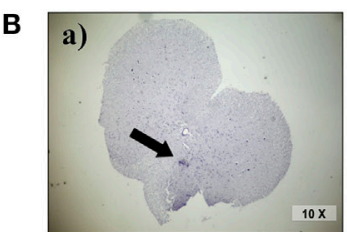
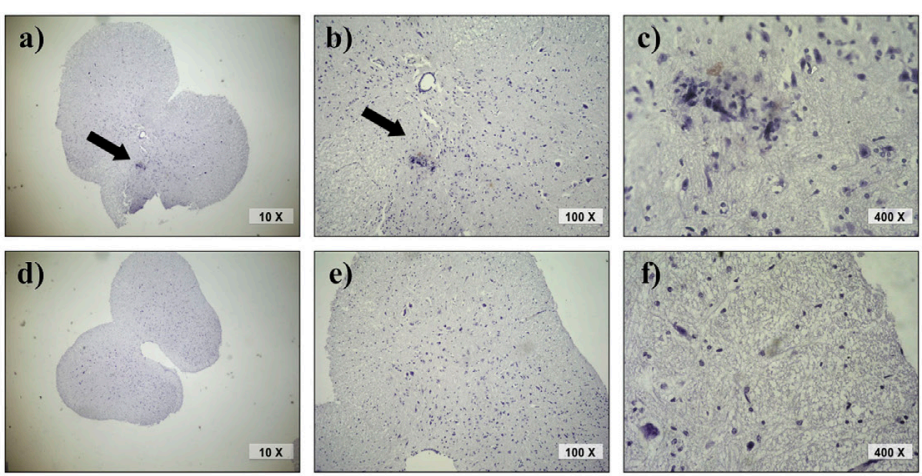

C

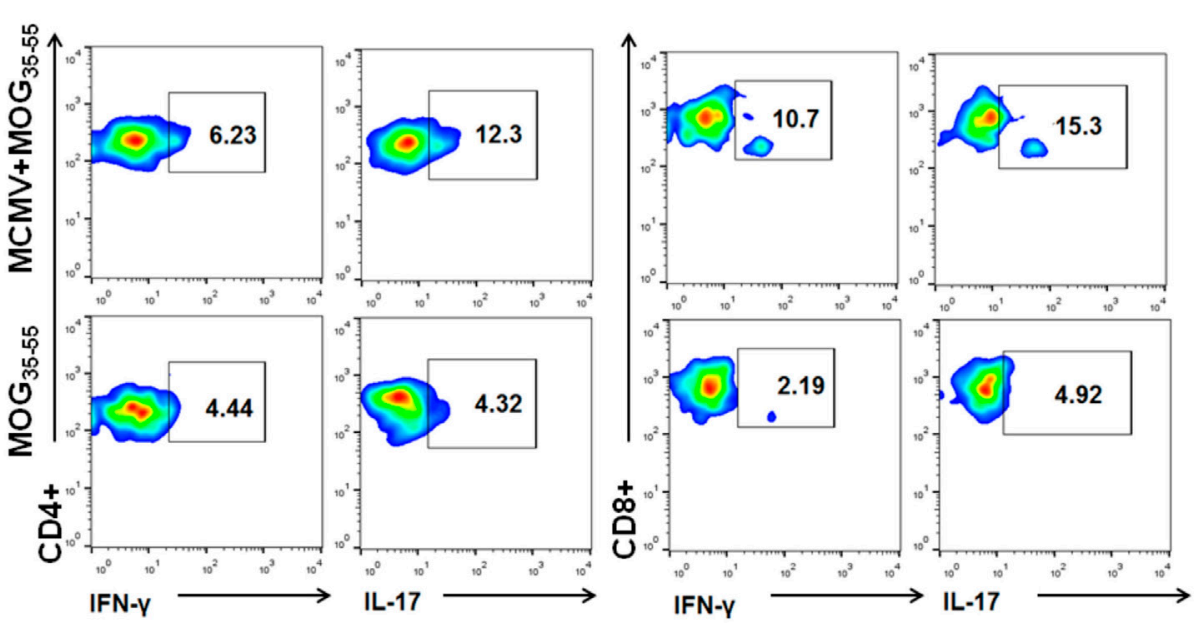

FIGURE 4 | BALB/c mice with latent murine cytomegalovirus (MCMV) infection develop experimental autoimmune encephalomyelitis and longlasting infiltrates in central nervous system. Mice were infected with MCMV, and 3 months later they were immunized with MOG $_{35-55}$ peptide, and disease was evaluated for 60 days. (A) Mean clinical score and (B) representative images of spinal cord sections 60 days after immunization with MOG $_{35-55}$ peptide in $\mathrm{MCMV}+\mathrm{MOG}_{35-55}$ group $(\mathrm{a}-\mathrm{C})$ and $\mathrm{MOG}_{35-55}$ group $(\mathrm{d}-\mathrm{f})$. (C) Representative flow cytometric images presenting percentages of IL-17- and IFN- $\gamma$-expressing $\mathrm{CD} 4^{+}$ and $\mathrm{CD}^{+}$cells among mononuclear cells isolated from brains 60 days after immunization with $\mathrm{MOG}_{35-55}$ peptide. Presented data are from representative experiment with seven mice per group.

(CD206) in the population of microglia $\left(\mathrm{CD} 45^{\text {int }} \mathrm{CD} 11 \mathrm{~b}^{+}\right)$in healthy mice, $\mathrm{MOG}_{35-55}$-immunized mice, MCMV-infected, and $\mathrm{MCMV}+\mathrm{MOG}_{35-55}$ mice. As shown in Figure 5F, microglia of mice with viral infection in adult life, with and without EAE, had proinflammatory, M1 phenotype. Significantly higher percentage of CD11c-expressing cells in microglia population was found in both groups of infected mice compared to healthy and $\mathrm{MOG}_{35-55^{-}}$ immunized mice. On the other hand, the highest percentage of (type 2) CD206-expressing microglia was found in $\mathrm{MOG}_{35-55}$ $\mathrm{BALB} / \mathrm{c}$ mice. Higher percentage of M2 microglia was also found in $\mathrm{MCMV}+\mathrm{MOG}_{35-55}$-immunized mice compared to healthy and MCMV-infected mice but lower compared to $\mathrm{MOG}_{35-55^{-}}$ immunized mice. Thus, high percentage of M2 microglia in mice at the peak of EAE could be also the compensatory mechanism that precedes disease attenuation.

\section{DISCUSSION}

Here, we provide the first evidence that MCMV infection results in breaking resistance of $\mathrm{BALB} / \mathrm{c}$ mice to EAE induction with
$\mathrm{MOG}_{35-55}$ peptide, as indicated by typical clinical manifestations and massive inflammatory infiltration in the CNS (Figure 1).

The role of MCMV infection in EAE is not studied, while its significance in MS is controversial. There are several prospective clinical studies that indicate protective effect of CMV infection on MS risk $(21,22,36)$, while recent well-powered meta-analysis found no significant difference in the rate of CMV seropositivity between MS patients and healthy controls based on pooled samples from all studies to date (37). On the other hand, CMV has been found in demyelinating plaques and the liquor of MS patients (15), and several clinical studies support the role of CMV in MS pathogenesis (18-20). Additionally, CMV infection induces expansion of inflammation-seeking/proinflammatory effector-memory $\mathrm{CD} 4^{+} \mathrm{CD} 28^{\text {null }} \mathrm{T}$ cells that are attracted to MS lesions via a CX3CL1 gradient $(38,39)$ and are mostly found in MS patients (40). Stimulation of these cells with myelin autoantigens results in their proliferation and release of cytotoxic granules, and thus may contribute to MS pathology (41). Some experimental animal studies support the role of CMV in EAE development. Cross-reactivity between $\mathrm{CMV}_{981-1,003}$ and $\mathrm{MOG}_{35-55}$ peptides was 

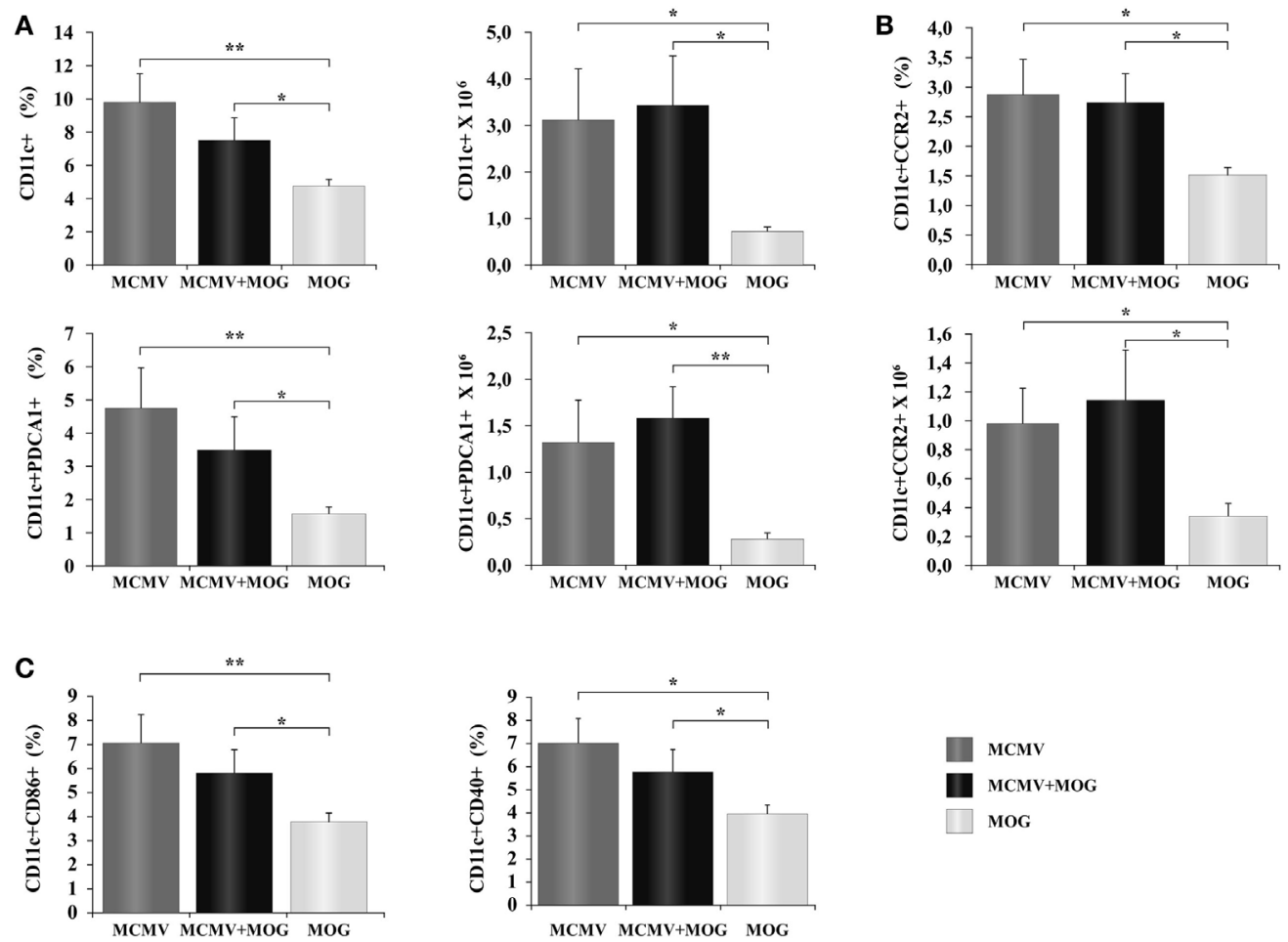

D
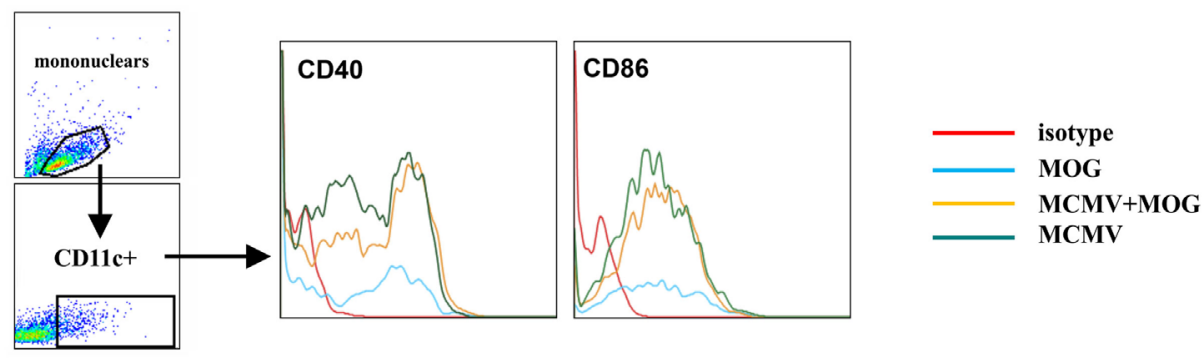

E
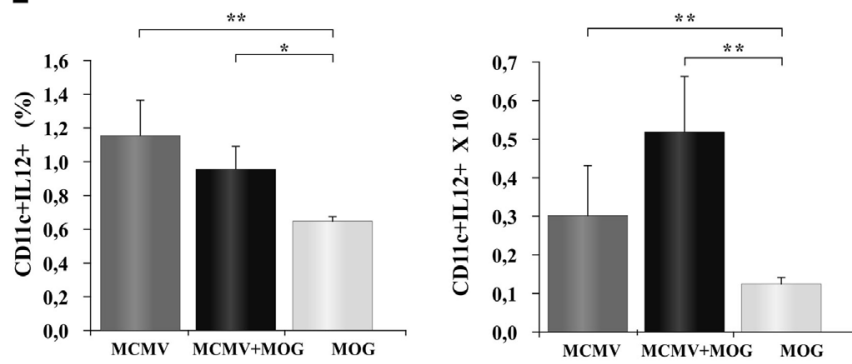

$\mathbf{F}$
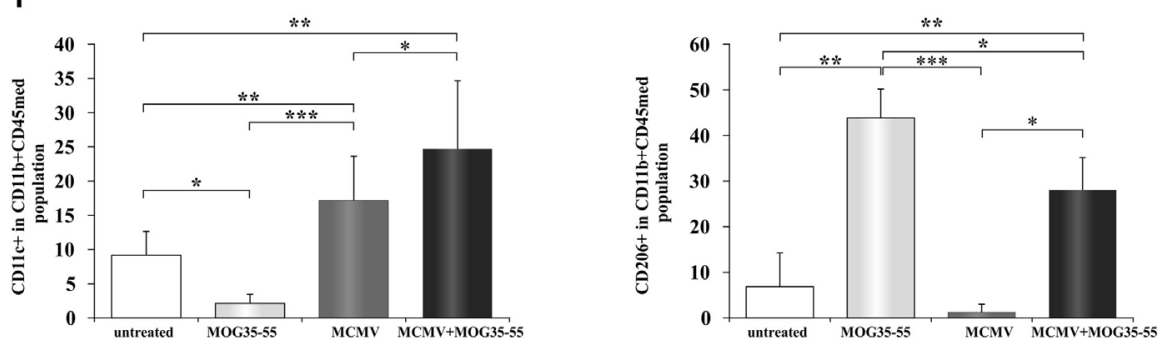

FIGURE 5 | Continued 


\section{FIGURE 5 | Continued}

Murine cytomegalovirus (MCMV) infection favors inflammatory phenotype of antigen-presenting cells. Mononuclear cells were isolated from inguinal lymph nodes 2 days after immunization with $\mathrm{MOG}_{35-55}$ peptide $\left(\mathrm{MOG}_{35-55}\right.$ ) and from lymph nodes of mice 10 days after their $\mathrm{MCMV}$ infection (MCMV). Flow cytometric analysis of dendritic cells phenotype was done. (A) Percentages and absolute numbers of CD11 ${ }^{+}$dendritic cells and CD11 $\mathrm{C}^{+} \mathrm{CD} 11 \mathrm{~b}-\mathrm{PDCA} 1^{+}$dendritic cells, (B) CCR2-expressing CD11 $\mathrm{C}^{+}$cells, and (C) CD86+ and CD40+ dendritic cells are presented as mean $+\mathrm{SE}$ (10 mice per group). (D) Representative histograms of CD40 and CD86 expression in CD11 $\mathrm{C}^{+}$population. (E) Percentages and absolute numbers of IL-12+ dendritic cells presented as mean + SE $(10$ mice per group). (F) Mononuclear cells were isolated from central nervous system of saline-treated, MOG 35 -55-immunized, MCMV-infected, and MCMV-infected and $\mathrm{MOG}_{35-55}$-immunized mice, 15 days after $\mathrm{MOG}_{35-55}$ immunization percentages of classically $\left(\mathrm{CD} 11 \mathrm{C}^{+}\right)$and alternatively $\left(\mathrm{CD}^{2} \mathrm{O6}{ }^{+}\right)$microglia are presented as mean + SE (8-10 mice per group). Data were analyzed with Student's $t$-test and ANOVA: ${ }^{*} P<0.05,{ }^{\star \star} P<0.005$, and ${ }^{* \star \star} P<0.001$.

found in Lewis rats immunized with $\mathrm{MOG}_{35-55}$ (42), while crossreactivity between $\mathrm{CMV}_{981-1,003}$ and $\mathrm{MOG}_{34-56}$ was found in rhesus monkeys (43). Immunization of rhesus monkeys with human $\mathrm{CMV}_{981-1,003}$ peptide induced expansion of $\mathrm{MOG}_{34-56}$-specific T cells (43). Female SJL/J mice primed with vaccinia virus that contain PLP gene and later challenged with MCMV-developed lesions in white matter regions in the brains (28). Other studies on primates also support the role of CMV in MS pathogenesis $(44,45)$. Recently, Juranic Lisnic et al. demonstrated that MCMV infection of murine fibroblasts induced highest expression of interferon $\beta$, transcriptional factor T-bet, chemokine CXCL10 (46), and the role of these markers of Th1 cells, in EAE pathogenesis is well known (47-49).

However, there was no evidence that MCMV infection may directly facilitate EAE. Here, we show that adult MCMV infection overcomes resistance of $\mathrm{BALB} / \mathrm{c}$ mice to induction of EAE with $\mathrm{MOG}_{35-55}$ peptide. The disease is characterized by typical clinical signs (Figure 1A) seen in susceptible C57BL/6 mice and massive brain and spinal cord infiltrations (Figures 1E,F). It should be noted that brain infiltrates are more significant in $\mathrm{BALB} / \mathrm{c}$ mice treated with encephalitogen then in "classical" EAE in C57BL/6 mice. It appears that the disease after infection $+\mathrm{MOG}_{35-55}$ challenge in otherwise resistant mice is more similar to MS than classical EAE (50). While in C57BL/ 6 mice, $\mathrm{CD} 4^{+}$cells dominate in CNS infiltrates in the experiments presented here, there was similar number of $\mathrm{CD}^{+}$and $\mathrm{CD}^{+}$cells in the infiltrates (Figure 1).

Encephalitogenity of $\mathrm{CD}^{+} \mathrm{T}$ cells in the infiltrates in BALB/c mice is further documented by their expression of chemokine receptors CXCR3 (Figure 2E), whose blockade during EAE induction attenuated the disease (51), and CCR6 receptor known to have the key role in development of initial autoimmune infiltration in the CNS $(52,53)$. While $\gamma \mathrm{HV}-68$ infection in C57BL/6 mice with EAE leads to almost exclusive infiltration with Th1 cells (7), in the CNS of MCMV-infected BALB/c mouse with EAE there is almost equal participation of Th1 and Th17 cellexpressing IFN- $\gamma$ and T-bet (Th1) and IL-17 and ROR $\gamma$ t (Th17) (Figures 2C,D). Moreover, inflammatory infiltrates in MCMVpretreated $\mathrm{BALB} / \mathrm{c}$ mice immunized with $\mathrm{MOG}_{35-55}$ contained $\mathrm{CD}^{+}$cell-expressing $\mathrm{T} 1$ and $\mathrm{T} 17$ transcriptional factors and corresponding cytokines TNF- $\alpha$ and IFN- $\gamma$ (Tc1) and IL-17 (Tc17 cells) (Figures 2C,D). Interestingly, it was suggested that Tc17 cells are required for Th17 accumulation and development of MS (54). Patients with early-stage MS harbor a greater number of Tc17 cells in the cerebrospinal fluid than in peripheral blood that contribute to the initiation of CNS autoimmunity (54). Since in the CNS of BALB/c mice with neonatal MCMV infection but without immunization with $\mathrm{MOG}_{35-55}$ dominates Tc1 cells (IFN- $\gamma$ and T-bet ${ }^{+}$) (55), it appears that the newly developing autoimmune process attracts a different population of $\mathrm{CD}^{+}$cells (IL-17 producing) that contribute to autoimmune process (54).

Significant accumulation of $\mathrm{CD}^{+}$cells in the infiltrates and their role in autoimmune pathogenesis is documented by clinical signs and typical pathology complemented by specificity of infiltrating cells. Ex vivo restimulation with $\mathrm{MOG}_{35-55}$ leads to significant increase of $\mathrm{CD}^{+}$cell-producing IFN- $\gamma$ in $\mathrm{MCMV}+\mathrm{MOG}_{35-55} \mathrm{BALB} / \mathrm{c}$ mice (Figure 3C). This finding is at variance with our finding in $\mathrm{C} 57 \mathrm{BL} / 6$ mice. $\mathrm{CD} 8^{+}$cells from EAE C57BL/6 mice did not responded to restimulation with $\mathrm{MOG}_{35-55}$ (Figure 3C). Further, $\mathrm{MOG}_{35-55}$ responsive $\mathrm{CD}^{+}$ cells in $\mathrm{MCMV}+\mathrm{MOG}_{35-55} \mathrm{BALB} / \mathrm{c}$ mice were not specific for viral epitopes pp89 and m164 (Figure 3D) implicating that $\mathrm{CD}^{+}$cell contributes to autoimmune process in this model of EAE. This finding is in line with previous report that initiation of autoimmune process in CNS with $\mathrm{CD} 4^{+} \mathrm{T}$ cells is followed with spreading to myelin-specific $\mathrm{CD}^{+} \mathrm{T}$ cells that are capable of direct recognition of oligodendrocytes and contribute to tissue damage (56). Similarly, heighten EAE in C57BL/6 mice infected with $\gamma \mathrm{HV}-68$ is accompanied with infiltration of brain parenchyma with $\mathrm{CD} 8^{+} \mathrm{IFN}-\gamma^{+}$granzyme ${ }^{+}$cells (7). However, specificity for autoantigen of these inflammatory and cytolytic $\mathrm{CD}^{+}$cells in $\gamma \mathrm{HV}-68$-infected C57BL/6 mice was not studied (7). Finding that mice with depletion of $\mathrm{CD} 4^{+}$cells after MCMV infection and before $\mathrm{MOG}_{35-55}$ immunization did not develop the disease (Figure 3A) contributes to the conclusion that MCMVinfected $\mathrm{BALB} / \mathrm{c}$ mice developed autoimmune neuropathology. Persistence of CNS infiltrations and $\mathrm{MOG}_{35-55}$-specific $\mathrm{CD}_{4}^{+}$ and $\mathrm{CD}^{+}$cells in $\mathrm{CNS}$ of BALB/c mice 2 months after $\mathrm{MOG}_{35-55}$ immunization that were infected 3 months previously (Figure 4) also proving autoimmune nature of the disease. Thus although $\mathrm{CD} 4^{+}$cells are required, it appears that $\mathrm{CD} 8^{+}$cells are the main effector cells.

MCMVinfection significantlyincreases proportion ofdendritic cells $\left(\mathrm{CD} 11 \mathrm{c}^{+}\right)$, plasmocitoid dendritic cells $\left(\mathrm{CD} 11 \mathrm{c}^{+} \mathrm{PDCA}^{+}\right)$in peripheral lymph nodes (Figure 5A) compared to immunization with $\mathrm{MOG}_{35-55}$. Further higher percentage of dendritic cells in lymph nodes in MCMV-infected mice is accompanied with higher percentage of $\mathrm{CCR}^{+}$dendritic cells (Figure $5 \mathrm{~B}$ ). It is known that MCMV encodes proinflammatory factor (MCK-2), analog of chemokine CCL2 (57) that enhances monocyte recruitment and viral dissemination (58). Then, higher percentage of dendritic cells in inguinal lymph nodes of MCMV-infected mice 
could be the consequence of CCL2 analog production, since CCL2 goes to lymph nodes where is presented on the surface of high endothelial venules for recruitment of monocytes (59). Although it was previously shown that MCMV attracts monocytes that have the immunosuppressive role (60), here, we found higher percentage of dendritic cell-expressing markers of activation CD86 and CD40 (Figure 5C) and containing Th1 promoting cytokine, IL-12 (Figures 5D,E). Our results indicate that MCMV infection of BALB/c mice induces increase of inflammatory dendritic cells in peripheral lymph nodes and thus enables development of encephalitogenic T cells. This finding is in correlation with previous report that MCMV-infected mice are resistant to bacterial infection due to prolonged production of the antiviral cytokine IFN- $\gamma$ and systemic activation of macrophages (61). Significantly, there was an increase of classically activated microglia $\left(\mathrm{CD} 45^{\mathrm{med}} \mathrm{CD} 11 \mathrm{~b}^{+} \mathrm{CD} 11 \mathrm{c}^{+}\right)$in the CNS of BALB/c mice 25 days after MCMV infection compared to $\mathrm{MOG}_{35-55}$-immunized mice without previous infection that had mostly alternatively activated microglia $\left(\mathrm{CD} 45^{\text {med }} \mathrm{CD} 11 \mathrm{~b}^{+} \mathrm{CD} 206^{+}\right.$) (Figure 5F). Lower percentage of alternatively activated microglia in $\mathrm{MCMV}+\mathrm{MOG}_{35-55}$ mice observed on day 15 after immunization and day 25 after infection in compared to $\mathrm{MOG}_{35-55}$ treated mice, and prevalence of M1 microglia in virus-infected mice may contribute to chronic disease in MCMV-infected $\mathrm{MOG}_{35-55}$-immunized $\mathrm{BALB} / \mathrm{c}$ mice. Previously, it was shown that systemic MCMV infection elicited a

\section{REFERENCES}

1. Hemmer B, Nessler S, Zhou D, Kieseier B, Hartung HP. Immunopathogenesis and immunotherapy of multiple sclerosis. Nat Clin Pract Neurol (2006) 2(4):201-11. doi:10.1038/ncpneuro0154

2. Sibley WA, Bamford CR, Clark K. Clinical viral infections and multiple sclerosis. Lancet (1985) 2(8441):1313-5.

3. Johnson RT. The virology of demyelinating diseases. Ann Neurol (1994) 36(Suppl):S54-60.

4. Soldan SS, Jacobson S. Role of viruses in etiology and pathogenesis of multiple sclerosis. Adv Virus Res (2001) 56:517-55. doi:10.1016/S0065-3527(01) 56037-6

5. Ascherio A, Munger KL. Environmental risk factors for multiple sclerosis. Part I: the role of infection. Ann Neurol (2007) 61(4):288-99. doi:10.1002/ ana. 21117

6. Angelini DF, Serafini B, Piras E, Severa M, Coccia EM, Rosicarelli B, et al. Increased CD8+ $\mathrm{T}$ cell response to Epstein-Barr virus lytic antigens in the active phase of multiple sclerosis. PLoS Pathog (2013) 9(4):e1003220. doi:10.1371/journal.ppat.1003220

7. Casiraghi C, Shanina I, Cho S, Freeman ML, Blackman MA, Horwitz MS. Gammaherpesvirus latency accentuates EAE pathogenesis: relevance to Epstein-Barr virus and multiple sclerosis. PLoS Pathog (2012) 8(5):e1002715. doi:10.1371/journal.ppat.1002715

8. Krishnamoorthy G, Wekerle H. EAE: an immunologist's magic eye. Eur J Immunol (2009) 39(8):2031-5. doi:10.1002/eji.200939568

9. Johnson TA, Jirik FR, Fournier S. Exploring the roles of CD8(+) T lymphocytes in the pathogenesis of autoimmune demyelination. Semin Immunopathol (2010) 32:197-209. doi:10.1007/s00281-010-0199-7

10. Dendrou CA, Fugger L, Friese MA. Immunopathology of multiple sclerosis. Nat Rev Immunol (2015) 15(9):545-58. doi:10.1038/nri3871

11. Mix E, Meyer-Rienecker H, Zettl UK. Animal models of multiple sclerosis for the development and validation of novel therapies - potential and limitations. J Neurol (2008) 255(Suppl 6):7-14. doi:10.1007/s00415-008-6003-0

12. Hanley PJ, Bollard CM. Controlling cytomegalovirus: helping the immune system take the lead. Viruses (2014) 6(6):2242-58. doi:10.3390/ v6062242 significant increase in the number of microglia with morphological signs of activation and M1 phenotype (62). Thus, it appears that at least one level of resistance of $\mathrm{BALB} / \mathrm{c}$ mice to $\mathrm{EAE}$ is the inability to convert microglia into M1 phenotype.

In summing up, we report here that MCMV infection may promote autoimmune neuropathology and convert resistant mice into susceptible to EAE induction. This was achieved by activation of antigen-presenting cells and promoting M1 phenotype of microglia as well as participation of $\mathrm{CD} 8^{+}$encephalitogen-specific $\mathrm{T}$ cells in the autoimmune pathogenesis.

\section{AUTHOR CONTRIBUTIONS}

Conceived and designed the experiments: JM, MM, NA, SJ, and ML. Performed the experiments: JM, BP, MM, AA, BS, and DK. Analyzed the data: JM, BP, MM, DK, IT, and AK. Wrote the paper: JM and ML.

\section{ACKNOWLEDGMENTS}

This work was funded by grants from the Serbian Ministry of Science and Technological Development (Grants No. ON175071, ON175069, and ON175103), Serbia, and the Faculty of Medical Sciences, University of Kragujevac (MP 01/14 and MP 02/14). The authors thank Milan Milojevic for excellent technical assistance.

13. Koch S, Larbi A, Ozcelik D, Solana R, Gouttefangeas C, Attig S, et al. Cytomegalovirus infection: a driving force in human $\mathrm{T}$ cell immunosenescence. Ann N Y Acad Sci (2007) 1114:23-35. doi:10.1196/annals.1396.043

14. Sinclair J. Human cytomegalovirus: latency and reactivation in the myeloid lineage. J Clin Virol (2008) 41(3):180-5. doi:10.1016/j.jcv.2007.11.014

15. Smyk DS, Alexander AK, Walker M, Walker M. Acute disseminated encephalomyelitis progressing to multiple sclerosis: are infectious triggers involved? Immunol Res (2014) 60(1):16-22. doi:10.1007/s12026-014-8499-y

16. 't Hart BA, Hintzen RQ, Laman JD. Multiple sclerosis - a response-todamage model. Trends Mol Med (2009) 15(6):235-44. doi:10.1016/j. molmed.2009.04.001

17. Scotet E, Peyrat MA, Saulquin X, Retiere C, Couedel C, Davodeau F, et al. Frequent enrichment for CD8 $\mathrm{T}$ cells reactive against common herpes viruses in chronic inflammatory lesions: towards a reassessment of the physiopathological significance of $\mathrm{T}$ cell clonal expansions found in autoimmune inflammatory processes. Eur J Immunol (1999) 29(3):973-85.

18. Sanadgol N, Ramroodi N, Ahmadi GA, Komijani M, Moghtaderi A, Bouzari $\mathrm{M}$, et al. Prevalence of cytomegalovirus infection and its role in total immunoglobulin pattern in Iranian patients with different subtypes of multiple sclerosis. New Microbiol (2011) 34(3):263-74.

19. Horakova D, Zivadinov R, Weinstock-Guttman B, Havrdova E, Qu J, TamañoBlanco M, et al. Environmental factors associated with disease progression after the first demyelinating event: results from the multi-center SET study. PLoS One (2013) 8(1):e53996. doi:10.1371/journal.pone.0053996

20. Weinstock-Guttman B, Horakova D, Zivadinov R, Tamaño-Blanco $\mathrm{M}$, Badgett D, Tyblova $\mathrm{M}$, et al. Interactions of serum cholesterol with anti-herpesvirus responses affect disease progression in clinically isolated syndromes. J Neuroimmunol (2013) 263(1-2):121-7. doi:10.1016/j.jneuroim. 2013.07.010

21. Sundqvist E, Bergström T, Daialhosein H, Nyström M, Sundström P, Hillert J, et al. Cytomegalovirus seropositivity is negatively associated with multiple sclerosis. Mult Scler (2014) 20(2):165-73. doi:10.1177/1352458513494489

22. Zivadinov R, Nasuelli D, Tommasi MA, Serafin M, Bratina A, Ukmar M, et al. Positivity of cytomegalovirus antibodies predicts a better clinical and radiological outcome in multiple sclerosis patients. Neurol Res (2006) 28(3):262-9. doi:10.1179/016164106X98134 
23. Jackson SE, Mason GM, Wills MR. Human cytomegalovirus immunity and immune evasion. Virus Res (2011) 157(2):151-60. doi:10.1016/ j.virusres.2010.10.031

24. Noriega V, Redmann V, Gardner T, Tortorella D. Diverse immune evasion strategies by human cytomegalovirus. Immunol Res (2012) 54(1-3):140-51. doi:10.1007/s12026-012-8304-8

25. Milovanovic M, Volarevic V, Ljujic B, Radosavljevic G, Jovanovic I, Arsenijevic $\mathrm{N}$, et al. Deletion of IL-33R (ST2) abrogates resistance to EAE in BALB/C mice by enhancing polarization of APC to inflammatory phenotype. PLoS One (2012) 7(9):e45225. doi:10.1371/journal.pone.0045225

26. Jiang HR, Milovanović M, Allan D, Niedbala W, Besnard AG, Fukada SY, et al. IL-33 attenuates EAE by suppressing IL-17 and IFN- $\gamma$ production and inducing alternatively activated macrophages. Eur J Immunol (2012) 42(7):1804-14. doi:10.1002/eji.201141947

27. Vanheusden M, Stinissen P, 't Hart BA, Hellings N. Cytomegalovirus: a culprit or protector in multiple sclerosis? Trends Mol Med (2015) 21(1):16-23. doi:10.1016/j.molmed.2014.11.002

28. Fujinami RS, von Herrath MG, Christen U, Whitton JL. Molecular mimicry, bystander activation, or viral persistence: infections and autoimmune disease. Clin Microbiol Rev (2006) 19(1):80-94. doi:10.1128/CMR.19.1. 80-94.2006

29. Wagner M, Jonjic S, Koszinowski UH, Messerle M. Systematic excision of vector sequences from the BAC-cloned herpesvirus genome during virus reconstitution. J Virol (1999) 73(8):7056-60.

30. Stromnes IM, Goverman JM. Active induction of experimental allergic encephalomyelitis. Nat Protoc (2006) 1(4):1810-9. doi:10.1038/nprot.2006.285

31. Stromnes IM, Goverman JM. Passive induction of experimental allergic encephalomyelitis. Nat Protoc (2006) 1(4):1952-60. doi:10.1038/ nprot.2006.284

32. Wraith DC, Pope R, Butzkueven H, Holder H, Vanderplank P, Lowrey P, et al. A role for galanin in human and experimental inflammatory demyelination. Proc Natl Acad Sci U S A (2009) 106(36):15466-71. doi:10.1073/ pnas. 0903360106

33. Halenius A, Hengel H. Human cytomegalovirus and autoimmune disease. Biomed Res Int (2014) 2014:472978. doi:10.1155/2014/472978

34. Raghavendra V, Tanga FY, DeLeo JA. Complete Freunds adjuvant-induced peripheral inflammation evokes glial activation and proinflammatory cytokine expression in the CNS. Eur J Neurosci (2004) 20(2):467-73. doi:10.1111/j.1460-9568.2004.03514.x

35. Qin L, Wu X, Block ML, Liu Y, Breese GR, Hong JS, et al. Systemic LPS causes chronic neuroinflammation and progressive neurodegeneration. Glia (2007) 55(5):453-62. doi:10.1002/glia.20467

36. Waubant E, Mowry EM, Krupp L, Chitnis T, Yeh EA, Kuntz N, et al. Common viruses associated with lower pediatric multiple sclerosis risk. Neurology (2011) 76(23):1989-95. doi:10.1212/WNL.0b013e31821e552a

37. Pakpoor J, Pakpoor J, Disanto G, Giovannoni G, Ramagopalan SV. Cytomegalovirus and multiple sclerosis risk. J Neurol (2013) 260(6):1658-60. doi:10.1007/s00415-013-6912-4

38. Broux B, Pannemans K, Zhang X, Markovic-Plese S, Broekmans T, Eijnde BO, et al. CX(3)CR1 drives cytotoxic CD4(+)CD28(-) T cells into the brain of multiple sclerosis patients. J Autoimmun (2012) 38(1):10-9. doi:10.1016/ j.jaut.2011.11.006

39. Pinto-Medel MJ, García-León JA, Oliver-Martos B, López-Gómez C, Luque G, Arnáiz-Urrutia C, et al. The CD4+ T-cell subset lacking expression of the CD28 costimulatory molecule is expanded and shows a higher activation state in multiple sclerosis. J Neuroimmunol (2012) 243(1-2):1-11. doi:10.1016/ j.jneuroim.2011.11.008

40. Thewissen M, Somers V, Hellings N, Fraussen J, Damoiseaux J, Stinissen P. CD4+CD28null $\mathrm{T}$ cells in autoimmune disease: pathogenic features and decreased susceptibility to immunoregulation. JImmunol (2007) 179(10):6514-23. doi:10.4049/jimmunol.179.10.6514

41. Broux B, Markovic-Plese S, Stinissen P, Hellings N. Pathogenic features of CD4+CD28- T cells in immune disorders. Trends Mol Med (2012) 18(8): 446-53. doi:10.1016/j.molmed.2012.06.003

42. Zheng MM, Zhang XH. Cross-reactivity between human cytomegalovirus peptide 981-1003 and myelin oligodendroglia glycoprotein peptide 35-55 in experimental autoimmune encephalomyelitis in Lewis rats. Biochem Biophys Res Commun (2014) 443(3):1118-23. doi:10.1016/j.bbrc.2013.12.122
43. Brok HP, Boven L, van Meurs M, Kerlero de Rosbo N, Celebi-Paul L, Kap YS, et al. The human CMV-UL86 peptide 981-1003 shares a crossreactive T-cell epitope with the encephalitogenic MOG peptide 34-56, but lacks the capacity to induce EAE in rhesus monkeys. J Neuroimmunol (2007) 182(1-2):135-52. doi:10.1016/j.jneuroim.2006.10.010

44. Wroblewska Z, Gilden D, Devlin M, Huang ES, Rorke LB, Hamada T, et al. Cytomegalovirus isolation from a chimpanzee with acute demyelinating disease after inoculation of multiple sclerosis brain cells. Infect Immun (1979) 25(3):1008-15.

45. Jagessar SA, Kap YS, Heijmans N, van Driel N, van Straalen L, Bajramovic JJ, et al. Induction of progressive demyelinating autoimmune encephalomyelitis in common marmoset monkeys using MOG34-56 peptide in incomplete Freund adjuvant. J Neuropathol Exp Neurol (2010) 69(4):372-85. doi:10.1097/ NEN.0b013e3181d5d053

46. Juranic Lisnic V, Babic Cac M, Lisnic B, Trsan T, Mefferd A, Das Mukhopadhyay $\mathrm{C}$, et al. Dual analysis of the murine cytomegalovirus and host cell transcriptomes reveal new aspects of the virus-host cell interface. PLoS Pathog (2013) 9(9):e1003611. doi:10.1371/journal.ppat.1003611

47. Yang Y, Weiner J, Liu Y, Smith AJ, Huss DJ, Winger R, et al. T-bet is essential for encephalitogenicity of both Th1 and Th17 cells. J Exp Med (2009) 206(7):1549-64. doi:10.1084/jem.20082584

48. Lalor SJ, Segal BM. Th1-mediated experimental autoimmune encephalomyelitis is CXCR3 independent. Eur J Immunol (2013) 43(11):2866-74. doi:10.1002/eji.201343499

49. Carter SL, Müller M, Manders PM, Campbell IL. Induction of the genes for Cxcl9 and Cxcl10 is dependent on IFN-gamma but shows differential cellular expression in experimental autoimmune encephalomyelitis and by astrocytes and microglia in vitro. Glia (2007) 55(16):1728-39. doi:10.1002/glia.20587

50. Babbe H, Roers A, Waisman A, Lassmann H, Goebels N, Hohlfeld R, et al. Clonal expansions of $\mathrm{CD} 8(+) \mathrm{T}$ cells dominate the $\mathrm{T}$ cell infiltrate in active multiple sclerosis lesions as shown by micromanipulation and single cell polymerase chain reaction. J Exp Med (2000) 192(3):393-404. doi: 10.1084/ jem.192.3.393

51. Sporici R, Issekutz TB. CXCR3 blockade inhibits T-cell migration into the CNS during EAE and prevents development of adoptively transferred, but not actively induced, disease. Eur J Immunol (2010) 40(10):2751-61. doi:10.1002/ eji.200939975

52. Reboldi A, Coisne C, Baumjohann D, Benvenuto F, Bottinelli D, Lira S, et al. C-C chemokine receptor 6-regulated entry of TH-17 cells into the CNS through the choroid plexus is required for the initiation of EAE. Nat Immunol (2009) 10(5):514-23. doi:10.1038/ni.1716

53. Liston A, Kohler RE, Townley S, Haylock-Jacobs S, Comerford I, Caon AC, et al. Inhibition of CCR6 function reduces the severity of experimental autoimmune encephalomyelitis via effects on the priming phase of the immune response. J Immunol (2009) 182(5):3121-30. doi:10.4049/jimmunol.0713169

54. Huber M, Heink S, Pagenstecher A, Reinhard K, Ritter J, Visekruna A, et al. IL-17A secretion by CD8+ T cells supports Th17-mediated autoimmune encephalomyelitis. JClin Invest (2013) 123(1):247-60. doi:10.1172/ JCI63681

55. Bantug GR, Cekinovic D, Bradford R, Koontz T, Jonjic S, Britt WJ. CD8+ $\mathrm{T}$ lymphocytes control murine cytomegalovirus replication in the central nervous system of newborn animals. J Immunol (2008) 181(3):2111-23. doi:10.4049/jimmunol.181.3.2111

56. Ji Q, Castelli L, Goverman JM. MHC class I-restricted myelin epitopes are cross-presented by Tip-DCs that promote determinant spreading to CD8? T cells. Nat Immunol (2013) 14(3):254-61. doi:10.1038/ni.2513

57. Saederup N, Aguirre SA, Sparer TE, Bouley DM, Mocarski ES. Murine cytomegalovirus CC chemokine homolog MCK-2 (m131-129) is a determinant of dissemination that increases inflammation at initial sites of infection. $J$ Virol (2001) 75:9966-76. doi:10.1128/JVI.75.20.9966-9976.2001

58. Noda S, Aguirre SA, Bitmansour A, Brown JM, Sparer TE, Huang J, et al. Cytomegalovirus MCK-2 controls mobilization and recruitment of myeloid progenitor cells to facilitate dissemination. Blood (2006) 107:30-8. doi:10.1182/blood-2005-05-1833

59. Palframan RT, Jung S, Cheng G, Weninger W, Luo Y, Dorf M, et al. Inflammatory chemokine transport and presentation in HEV: a remote control mechanism for monocyte recruitment to lymph nodes in inflamed tissues. J Exp Med (2001) 194:1361-73. doi:10.1084/jem.194.9.1361 
60. Daley-Bauer LP, Wynn GM, Mocarski ES. Cytomegalovirus impairs antiviral CD8+ $\mathrm{T}$ cell immunity by recruiting inflammatory monocytes. Immunity (2012) 37(1):122-33. doi:10.1016/j.immuni.2012.04.014

61. Barton ES, White DW, Cathelyn JS, Brett-McClellan KA, Engle M, Diamond MS, et al. Herpesvirus latency confers symbiotic protection from bacterial infection. Nature (2007) 447(7142):326-9. doi:10.1038/ nature 05762

62. Zinkernagel MS, Chinnery HR, Ong ML, Petitjean C, Voigt V, McLenachan $\mathrm{S}$, et al. Interferon $\gamma$-dependent migration of microglial cells in the retina after systemic cytomegalovirus infection. Am J Pathol (2013) 182(3):875-85. doi:10.1016/j.ajpath.2012.11.031
Conflict of Interest Statement: The authors declare that the research was conducted in the absence of any commercial or financial relationships that could be construed as a potential conflict of interest.

Copyright (C) 2017 Milovanovic, Popovic, Milovanovic, Kvestak, Arsenijevic, Stojanovic, Tanaskovic, Krmpotic, Arsenijevic, Jonjic and Lukic. This is an open-access article distributed under the terms of the Creative Commons Attribution License (CC BY). The use, distribution or reproduction in other forums is permitted, provided the original author(s) or licensor are credited and that the original publication in this journal is cited, in accordance with accepted academic practice. No use, distribution or reproduction is permitted which does not comply with these terms. 